\title{
JOSEPH HELLER'S NOVEL “PORTRAIT OF AN ARTIST, AS AN OLD MAN” AS THE LATE STYLE WRITING
}

\author{
Yana Dudar \\ Postgraduate Student, Oles Honchar Dnipro National University, Ukraine \\ e-mail: yanadudar@ymail.com, orcid.org/0000-0002-2983-2308
}

\section{Summary}

The article is devoted to the study of the thematic and poetic features of the late prose "Portrait of an Artist, as an Old Man" of the American writer Joseph Heller. Developing the concept of lateness Theodor W. Adorno and Edward W. Said discovered that the last work may possess hidden complexity under the illusional formal simplicity. Risk and rebellion became the main motives in Heller's novel as he goes to rediscover The Great American Novel and compare himselflnarrative "reflection" with its creators. The author turns reader's attention to the problem of perception of a writer, composing the theory of "literature of despair" as the visible foe he stands against.

This paper aims to discover the distinguishing difference between previous and last novels, foremost in changing the poetics of absurdism and existentialism. The author intentionally depicting himself as an ironic figure Eugene Pota that "is" writing his last novel here and now. This character is a reflected image of Heller himself, through which he analyzes his life and work. The choice to frame the whole narrative as the metaphorical odyssey of Tom Sawyer in search of a literary mentor resonates with John Bart's essay about "literature of exhaustion". A complicated canvas of plots, - rewriting Kafka, Twain, Bible - allows to explore gender roles in the narrative, redirect well-known stories into postmodern patterns. The late style appears as the result of history - bringing the forgotten pieces of conventional fictional techniques in an unexpected manner.

Heller overcomes the despair before his own death and audience criticism because he strongly believes that art will continue to live.

Keywords: American literature, postmodernism, absurdism, existentialism, autobiography, narrative.

DOI: https://doi.org/10.23856/4003

\section{Introduction}

Theodor W. Adorno, who presented the concept of the late style in 1936 in his famous essay called "Late Style in Beethoven", proclaimed a problem that was, and still is relevant to all art in general. He pointed on the tendency in academia and critique circles to mark any artist's last work as "aesthetic catastrophe", if they simply have not met the significant criteria of their, usually early, and most prominent masterpiece. Such pieces of art could not be defined by the audience as a perfect final chord, and, according to the Adorno, leads to the wrongful and sometimes harmful interpretation and reception, that might obstruct and make it nearly impossible to assess its unique beauty and significance in terms of the history of art.

The controversy of the late style lies in the special and barely perceptible tone of the work: oneself death magnetic. An artist that goes toward his finality might turn onto the two main topics: oneself versus contemporary social problems, and/or versus 'previous' oneself. 
Distinctive ambiguous might be revealed in the construction of a special, inner landscape of the work, which emphasizes the conscious choice of the artist to challenge through the last workhis last performance the own oeuvre. In this journey an artist returns to the very beginning of his artistic roots, which might symbolize the closing of the circle 'start-end'; puts together, as could be seen as conventional, but meticulously structured pieces of own techniques that denotes experiment, rather than a new phase of artistic development. The rediscovered power of subjective expression, as defined by Adorno, undoubtedly might contain, and connect to autobiographical motives, which should not obscure, but expand the layers of interpretation, and genre definition.

Edward W. Said in his posthumously published work "On Late Style: Music and Literature Against the Grain” (Said, 2006) not only revisited the main postulates of Adorno's original theory but made significant additions. Started on a music theory base, he translated the subject onto literary arts, bringing the analysis of such figures as William Shakespeare, Constantine P. Cavafy, Jean Genet, Thomas Mann, Henrik Ibsen, and Giuseppe Tomasi di Lampedusa. In particular, he applied the late style in the literary direction, considering the works of J. Genet, T. de Lampedusa, C. Cavafy, briefly mentioning W. Shakespeare, T. Mann, G. Ibsen, T. Adorno. Artists entering the late stage of creativity. On the example of Chopin, he explained that an artist may become "the late figure" regardless of his age, and transformed the idea of "lyrical loneliness" brought by Adorno into the concept of 'exile', which stands as fundamental in his view.

Literary criticism has only recently begun to affirm the late style, which allows to pursue new directions in the literary theory of modernism and postmodernism.

The main goal of this article is to define the main features of Joseph Heller's late style. Eventually, through the comparative methodology, it will contribute to the general theory of the late style of American postmodernism and establish a new approach to the analyzes of the lateness in literature.

Therefore, the study of the latest novel by Joseph Heller "Portrait of an Artist, as an Old Man" (2000) in terms of the late style concept has the potential to redefine the final image of the author and his career.

As mentioned above, most of the literary research gravitates toward the 'main' work or 'masterpiece', which in Heller's career is his first novel "Catch-22" (1961).

Joseph Ozias in his project at Ohio Dominican University tried to cover the whole Heller's path, but only brushed the last novel, claiming it as "the last shout into the void". The reader, he advises, needs to know the details of the author's biography to understand the novel. He ignores the obvious powerful self-ironic narrative and proclaims that Heller, as his character, wanted to become 'relevant' again for his audience by writing a "terrific swan song" (Ozias, 2017).

Studying the depth of Heller's poetics of absurdism, Tas mainly refers to the work of A. Camus" "The Myth of Sisyphus" and J-P. Sartre's "Existentialism and Humanism". Exploration of the philosophical vector leads to the conclusion that Yossarian as the main character of "Catch-22", through playing and mixing the name "Irving Washington" and "Washington Irving", tried to escape the senseless bureaucracy of the "catch-22" situation. The literary critic emphasizes that the military which Heller used for the plot, requires adaptation of one's being to its requirements, often interfering with the nihilistic lifestyle, which the protagonist is opposed to (Tas, 2017). One combination and coverage of different theoretical foundations of existentialism makes the novel a unique example of postmodern absurdism.

Famous literary critic and former chief book critic for The New York Times, Michiko Kakutani, expresses almost a remorse about Heller's admirers that it was published at all. She 
claims the novel's lack of literary skills and technique, which present in his other novels, even comparing to the sequel to "Catch-22" - "Closing Time" (1994). By definition "an old man's narcissistic rant" Kakutani notes his excessive "mortality obsession" and existential dilemma in dealing with frightening reality. According to the article, Heller represents a concentrate of his old fear of failure and the inevitable comparison with his first and overwhelming successful novel. The conclusion is expressing the disappointment of this "anti-climactic" no more than "a poor imitation of a novel" (Kakutani, 2000). Under the ironic and neglecting passages was missed the connection with Barth's essay "Literature of exhaustion".

The last Heller's novel also remains poorly studied in Ukrainian literary criticism. The most recent and only fundamental work was presented by Y. S. Honcharova in her thesis dedicated to autobiography poetics. The phenomena of "parrhesia" (Foucault, 1983) could be used as the main approach to look at the "Portrait" as "truth-telling as a specific activity". The author is categorized as a real artist "parrhesiastes" (Goncharova, 2016: 75), which has two roles - as a man and an artist who tries to be honest with himself. The researcher considers the book as an innovative step in the genre of autobiography, a simultaneous combination of the technique of "erasing the face" and "creating a portrait" (Goncharova, 2016: 78). Summing up that only a gullible reader could perceive it "straightforwardly", which testifies in favor of our previous critical reviews, but the main thing is the "catch" of Heller himself - the main key to analysis - not all as obvious as it seems at first glance, it is not a "novel of decay", but a masterful work of destroying the general notion of the genre "portrait" (Goncharova, 2016: 88).

\section{Return to the roots}

The American writer Joseph Heller is best known for his first novel "Catch-22" (1961), which embodies the concept of the same title - the absurdism and contradiction that has become leading and recognizable through all his work. The idea comes from the French theater of the absurd, preserves the tone of tragicomedy through the image of war, puts a person in a rigid and forced "borderline situation", which refers to the original theory of K. Jaspers in the discussion of the mental state (Jaspers, 1952).

The last novel, published posthumously, "Portrait of an Artist, as an Old Man" (2000) is a complicated canvas of autobiographical allusions of one's life and metafiction experiments, made it possible to build a new narrative type that places him along with such authors like Kurt Vonnegut and John Barth and theirs late works "Timequake" (1997) and "Every Third Thought" (2011).

The title of Heller's work resonates thematically with James Joyce's first novel "A Portrait of the Artist as a Young Man" (1916) and is revealed in the artist's confrontation with circumstances that he is unable to change. Stephen/Joyce is a young Irish writer, realizes that his fellow citizens and political leaders, doomed to lose again and again in the struggle for freedom and independence. The character is constantly looking for someone who could become a figure of a father or a mentor; in contrast, Pota/Heller is another pair of dualistic self-incarnation and reflective personality, is an old American writer looking for a "Capital A" Author-mentor who could show the way to fight the despair of upcoming life end and the fear of creating the last novel. Literary critic Hugh Kenner in his preface to the novel of Joyce compares his innovative style as narrator to Charles Dickens' "Oliver Twist” (Joyce, 1991:7). And Heller intentionally frames into his novel a "rewriting" of Mark Twain's "The Adventures of Tom Sawyer". Both mid-19th century novels still evoke the image of great achievement that must be "inherited" by a new era. 
Language in both novels is one of the leading constructs of reality. Joyce's novel is a metaphorical "mirror" in which he depicts himself, his image, and therefore the sound of certain words, repetition through chiasm (Joyce, 1991: 13), and the emphasis on their derivatives is crucial in the composition and for the reader perception. If the Irish writer's main task was to emphasize his origin, his national "killed" language - Heller's language is modern American, sometimes vulgar, and explicit, which he explores through the "female" narrative perspective. In light humor tone author explores the boundaries of a feminine lexicon, positioning himself as the female character uses disparagement definition "cunt" regarding other women and "arse" (Heller, 2000: 126); reflects on what the dialogues between husband and wife could look like in intimate moments in the XVI century (Heller, 2000: 125-6); how women think about their body and other intimate things and what vocabulary they would use (Heller, 2000: 127). The integrate image is outlining the problem of understanding women and how unexplored feminine narrative keeps staying in any era. Also, Rene Rojas in his thesis "Language and the system: the closed world of Joseph Heller's fiction" (Rojas, 1994) draws attention to his special narrative technique - usage of "self-negating sentences", narrative repetitions, and circular structure. On the example of "Catch-22," he illustrates that a language is the main tool of conveying the chaos of war and absurdism, absorbed the essence of its time - aimed to confuse characters and the reader.

\section{Pota as self-projection}

The protagonist of the main narrative line - Eugene Pota (POTA is an acronym for "portrait of the artist" (Heller, 2000: 228)) is an old writer, an autobiographical projection of Heller, balancing within the linguistic representation of "we, he and I" (Heller, 2000: 40), "the elderly author and I" (Heller, 2000: 28) to enhance the effect of affinity. However, from time to time the writer emphasizes that he is the Author, distances from his narrative prototype Pota. Heller emphasizes that through Pota he completely controls the text and its composition, repeating and proving it through such constructions as "I want", "I could" and "I allowed": "His name was Eugene Pota, because that's what I want it to be $<\ldots>$ " (Heller, 2000: 36), "I let him recall right then the very good time long back $<\ldots>$ " "And then I allowed him to ruminate epistemologically on still another thought for this new book of ours $<\ldots>$ " and "I could make her anything I chose, wise and capable, noisy and narrow-minded, introverted and opinionated <..." (Heller, 2000: 60-61).

It is worth noting that the novel "Closing Time" (1994) (Heller, 1994), which is a sequel to "Catch-22", marks the transition to the late style of Heller due to a change in thematic load and focus on the characters. Yossarian, who survived the war, lived a long life and now an elderly man facing a different kind of his worst fear - death. He stops to be in the main writer's focus, replaced by new and young protagonists who struggle with the social problems of the American society of the 90 s. Despite everything the author still believes in the victory of common sense over the absurdity of this world.

At the very beginning of the "Portrait" Heller/Pota expresses the idea of the "future" work: "How about a novel, he joked to himself as a caprice, about a novel, with the novel itself as a narrator?" (Heller, 2000: 25), which, translated into a different type of fight with absurdism, that is one of the keys to understand the compositional method of narrative construction.

\section{Great American Novel as metafiction}

In metatextual terms, Heller primarily refers to and recreates the character of Tom Sawyer, who represents the "Great American Novel" - a magnitude, the unattainable height of 
the past. Ten years later John Barth in "Every Third Thought" (2011) will also look for such a lighthouse in the literary world by creating his own self-projection of an old writer. These two characters have the common goal - to write the last novel, which must be a special, new type of masterpiece in their own eyes, even if it might be labeled as "failure" by a common point of view, not praised as best while he is still alive: " $<\ldots>$ the grandiose determination that his next novel, possibly his last, should be hailed as among his best" (Heller, 2000: 44). The "Portrait" sections, labeled "Tom" or "Tom Sawyer, Novelist," focus on the character's futile attempts to meet the great writers of the past to get advice: how to write a novel, gain immortal fame, and get rich. In his imagination or, better say, by a created mythical images of each persona in terms of the history of art, all of them live a fabulously happy and sublime life, resting on the laurels of his fame in America or Europe.

It is no coincidence that the beginning and the end of the novel has a stylistic frame of Mark Twain's "The Adventures of Tom Sawyer". The power of the myth of its author and the character used both as allusion and metafiction. Emotional and stylistic regression is the way of the Heller to reflect on himself - a Tom Sawyer that reaches to the illusional immortality and greatness. He is a spoiled young man of the late twentieth century who is looking for an easy way to get rich and famous. His life is a fantasy and he does not care about reality. Tom is also Pota, going from one writer to another, trying to grasp a formula of their success. he inherited from the original Mark Twain's character a unique trait of confidence, independence, and ease of perception of the circumstances in which he finds himself and tries to get the most out of them. A century passed and Tom's character has also gone through some changes, as America did. Pota/Heller/Tom - they all are the united image of modern and past, carrying the spark of the American spirit.

First, Tom goes in search of Samuel Clements - Mark Twain, his creator, and finds out the shocking details of his life in recent years: depression due to financial setbacks, the death of his daughter, and overlooked works "The Man That Corrupted Hadleyburg" and "Pudd'nhead Wilson". Frustrated Tom decides to find another prominent figure and continues his journey, get money by selling signed copies of "The Adventures of Tom Sawyer". The narrator of this part, Pota/Heller, remarks bitterly that "The thought did not once cross his innocent mind that Samuel Clements, who'd authored The Adventures of Tom Sawyer, Tom Sawyer, Detective, and Tom Sawyer Abroad, had come to loathe that very name Tom Sawyer, as he now bitterly did very much else in the world around him." (Heller, 2000: 157). Heller himself experienced how the early success can eventually become a burden that later pulls down and overshadows all future work, defeats in advance every attempt to overturn the result. Dying in despair and oblivion, that even the giants of fiction of the past couldn't escape, - is his very own and personal fear in which he, as Yossarian, engaged in "borderline situation": ready for a fall, but hopes to rise.

Jack London, Bret Harte, Ambrose Bierce, Frank Norris, Stephen Crane - wherever Tom arrives he is already too late, writer is gone: "Alas, again his timing was bad; he was again too late" (Heller, 2000: 148). The narrator delves into the description of the last years of each of them, revealing tragic biographical details that haven't caught the general attention and not affected the final image, contrasting with the image of literary success at the beginning of their careers.

Also, Heller mentions writers whose last work contributed to the decline of their careers, in particular, about Herman Melville, he writes that "As with others whose best novels had brought demoralizing failure and a decline in reputation, Melville's final best efforts led to the ruination of his career as a writer and to his despair as a man." (Heller, 2000: 159). Along with American writers, he mentions Henry James, erasing geographical boundaries, composing the 
tendency that Adorno highlighted: " $<\ldots>$ a declining position in the world of literature; the successive, accumulating failures in popularity of his latest, deepest, largest, greatest novels, The Wings of Dove, The Ambassadors, The Golden Bowl, which had each been received with little praise, much belittlement, and small readership <..." (Heller, 2000: 154). This resonates with the concept of late style: last work usually perceived by author contemporaries as a catastrophe, the inability not only of general audience but also literary critique to see the final creation as the result of artistic style history, look deeper into it as the experiment. Under "history" is meant to be the stylistic essence concentrated and reinterpreted through the original path, which not stands on simple "autobiography" label. Despite the discourse of "The Death of the Author", Heller emphasize repeatedly that postmodernism still stands and empowers not only past images of Authors, but continually mythologize new one, which might lead inevitably to high criticism in case of attempt to get out of the imposed pattern. Therefore, authors also become fictional figures: "His travels through the literary hall of fame of America had steered him into a mortuary of a museum with the failed lives and careers of suffering heroes who were only human" (Heller, 2000: 160), means this is the result of the narrator's search for a mentor.

\section{Literature of despair}

Tom Sawyer's journey through the biographies of writers is linked by Heller to Pota's main narrative, an independent metaphorical illustration of his lecture entitled "Literature of despair" (Heller, 2000: 21). Explaining his thoughts in the style of an essay, he not only touches the problem of rational perception of all works of a specific writer but points on one's intentions to create works with a frantic taste. Although Pota describes himself as "a rank-conscious American author like Eugene Pota, one of many and typical of all <...” (Heller, 2000: 108). However, being old, as it turned out, also affects the creative work, and with bitterness the narrator asking himself: "where, he wondered, had ingenuity gone?" and recalls how "In earlier days of youthful mental vigor and stronger drive the dependable literary thoughts and inspirations that vaulted out of nowhere into mind whenever he beckoned for them had seemed inexhaustible." (Heller, 2000: 12). The artist finds himself in existential hardship: in "Catch-22" Yossarian asked himself "to die or not to die" (Heller, 1990: 71), now he is again reinterpreting Shakespeare by "write or not to write" manner. Next, he is quoting the words of Prospero from "The Tempest" comedy: "Shakespeare did know when to quit: "Our revels now are ended, "he wrote in The Tempest (Shakespeare, 1964), and departed with his winnings <... >" (Heller, 2000: 19). John Barth in his late style "Every Last Thought" novel implemented the Prospero model as one of the characters. Ned Prosper keeps the role of a foreteller, accepts the life and death as simple truth.

Pota/Heller could avoid joining the list of "despair" literary figures but made it obvious that he already chose to do exactly that because it is impossible to create a masterpiece without writing it. Such kind of existential dilemma also represents the idea of "catch-22" that could be applied only to late artists. He even quoting Samuel Beckett's "The Unnameable": "I must go on. I can't go on. I'll go on," (Heller, 2000: 21). Heller plays with the reader by luring him into different layers of explanation why uncontrollable and relentless desire to finish the career on a high note, proving his genius, first of all, to himself and putting his name in the history of literature once again is so necessary: "The artificer who lives long enough, particularly the writer of fictions for page and stage, may come to a time in his life when he feels he has nothing new to write about but wishes to continue anyway" (Heller, 2000: 19). As the narrative unfolds further, the author also changes the accentuation on the novel idea: "This is a book 
about a well-known, aging author trying to close out his career with a crowning achievement, with a laudable bang that would embellish his reputation rather than a fainthearted whimper that would bring him only condescension and insult" (Heller, 2000: 40). Adorno specifically emphasized that late style is the rebellion against the artist's style and audience expectations, the sole act of intention. All of those indicate the transition to one's lateness, the power to stand against problems that being silenced (Adorno, 2), mostly because the old artist might get away with the consequences of such a provocative move.

The contradiction between the desire to create the last piece of art almost for oneself, and the understanding that this last step would not be appreciated creates "despair" which Heller wants to overcome: " $<\ldots$. > early success leads invariably to greater, grandiose expectations and also, sooner or later, to lesser success, to decreased popularity, to more exacting scrutiny and exacting criticism - to which none of us is insensitive - and to feelings of failure, even when the new accomplishments are recognized." (Heller, 2000: 171). Heller alike Barth and his "literature of exhaustion" not only reveals one of the main problems of literature that succeeded modernism but rebels against it, presenting his novel as the main proof of injustice. The artist develops and changes his style throughout life, but only in lateness, he returns to the beginning, reexplores the potential of the craft and its purpose. Pota/Heller brings the rhetorical question, referring to Freud's theory (Freud, 1948) of frustration and desire: "What did they - we - hope to obtain when they - we - first hoped to succeed as a writer?" (Heller, 2000: 172). The author is not giving his answer but knows what he is expecting to obtain at the end of his life and career.

\section{Kafka rewriting}

The last narrative piece represents the rewriting of the famous novella by Franz Kafka "The Metamorphosis" (1906), which in Heller's perspective fits perfectly onto the landscape of modern America. The writer keeps the original poetics of absurdism and existentialism but changes the perception of exile and main context. A common man - Gregg Sanders (former Gregor Samsa) lives in Manhattan (New York) in the late twentieth century and works as a financial actuary. The first difference comes in the depiction of his family as "typical American" in an extremely negative light: a father is a "domestic despot", which gives "tough orders", "sarcastic criticism" and "stares darkly over one of its newspapers"; a mother is "the bullying autocrat", "spineless, subordinate, and obedient, and therefore unknowable" person; a sister is surprisingly ambitious and selfish, she immediately expressed the wish to occupy her brother's room, make it her office where she will write her book, and " $<\ldots>$ had insinuated herself up to the approval of the father for self-protection, gifts, and privilege.” (Heller, 2000: 96-97).

And Gregg is not so frightened by his transformation into the bug, only concerned that he was thrown out onto the streets. Being homeless - being in exile is what is seen as the real problem. Heller touches the sensitive topic of racial inequality in the next metaphor: "Who would you turn to if you were suddenly without money and unconnected to anyone who has any, or if all your life you've been white and suddenly you find yourself in the streets as a black?". This should not be considered as racist allegation but a sign of social disbalance that is so distant and invisible before: "There were, he'd been told by newspapers, thousands upon thousands of such beings doomed to live out their last days in that impoverished and debased state" (Heller, 2000: 100).

If Gregor felt "pain and aggravation" (Kafka, 2002: 10) and cherished the hope till the end to get his appearance back; Gregg, otherwise, got quickly used to his new self, felt a touch of pride, and liked the feeling of his muscles (Heller, 2000: 98), went to a place of his work 
and wanted to see his fiancé. The dynamic of the ending in Heller's narrative has a different direction: Gregg is looking for help - tried to reach his psychiatrist, physician, congressman, lawyer, senator, even the president but found out that all of them also were turned into a different creature that reflects their inner nature.

\section{Conclusions}

Joseph Heller's last work "Portrait of an Artist, as an Old Man" opens the dualistic world of the author's narrative personality, which, at the final stage of his life and career, immerse into the heavy existential depths as an artist and as a man. His main goal is to overcome despair as a premonition of the death and abdication of the creative path, the inevitable end of each writer.

By changing one recognizable narrative scene to another Heller not only skillfully represents the proto image of the artist/himself, but also touches the problems related to last works and their authors within the history of literature. At the same time, he builds another, more private dimension of the novel, concentrated on the themes of love and marriage, youth and maturity, career and recognition.

Heller's return to the literary "origins" became possible through the deepening of his perception of poetics of the absurdism and existentialism through interpretations and rewriting modernist, classical, and own plots. The journey of his own "self" that is incarnated into the postmodern Tom Sawyer and Eugene Pota, who both see in every late classic literature figure a mentor, is the brightest illustration of life circle. His desire to reach the perfection of the Great American Novel is also the piece of philosophy of absurdism. Heller joins the new tendency of high postmodernists who in their late novels reversing to and reflecting on the twentieth-century literature processes.

The novel heavily resonates with the theoretical principles of Theodor Adorno and Edward Said: the form of illusional "perfection" which is expected in the late novel might be hidden in the opposite. The late artist might take the risk and rebel against his style, destroy and reshape it with old techniques, connecting all pieces of craft. And Heller follows the same path by creating the theory of "literature of despair". He feels that this late novel -his biggest narrative experiment "must be written". Heller also finds himself in creative exile: he removes himself from the novel and creates his reflection \narrative image that tears the limits of classic autobiography, aiming to confuse the reader.

Further research of the late style may bring a new approach to understanding the postmodernism literary process.

\section{References}

Adorno, T. W. (2005). Critical Models: Interventions and Catchwords (European Perspectives: A Series in Social Thought and Cultural Criticism). (H. Pickford, Trans.). Columbia University Press.

Adorno, T. W. (2002), Leppert R. (Ed.). Essays on Music. (S. H. Gillespie, Trans.). University of California Press.

Barth, J. (1984). The Friday book: essays and other nonfiction. Putnam.

Barth, J. (2012). Every Third Thought: A Novel in Five Seasons. Counterpoint.

Foucault, M. (1983). Discourse \& Truth, Problematization of Parrhesia - Six lectures given by Michel Foucault at the University of California at Berkeley, Oct-Nov. 1983. https://foucault.info/parrhesia/foucault.DT6.conclusion.en/ 
Freud, S. (1948), Jones E. (Ed.). Beyond the pleasure principle. The international psycho-analytical library.

https://www.libraryofsocialscience.com/assets/pdf/freud_beyond_the_pleasure_principle.pdf Goncharova, Yu. S., Lipina, V. I. (2016). Poetika avtobiografizma v amerikanskoj literature konca XX-nachala XXI veka: kriticheskaya refleksiya i hudozhestvennaya praktika [The Poetics of Autobiography in American Literature of the Late Twentieth-Beginning of the Twenty First Century: Critical Reflection and Artistic Practice]. Dnepr. [in Russian]

Heller, J. (2000). Portrait of an Artist, as an Old Man. Simon \& Schuster.

Heller, J. (1990). Cath-22. Dell Pub.

Heller, J. (1994). Closing time. Simon \& Schuster.

Jaspers, K. (1952). Existentialism and humanism. R.F. Moore.

Joyce, J. (1991). A Portrait of the Artist as a Young Man. Signet Classic.

Kafka, F. (2002). Metamorphosis. (R. Strokes, Trans.). Hesperus Press.

Kakutani, M. (2000, May 30). Books of the times; Joseph Heller's Valedictory Holds a Mirror to Himself. New York Times.

https://www.nytimes.com/2000/05/30/books/books-of-the-times-joseph-heller-s-valedictoryholds-a-mirror-to-himself.html

Ozias, J. (2017). Joseph Heller and the Errors of Comedy: From Heller's Catch-22 to Portrait of an Artist, as an Old Man. Ohio Dominican University.

https://etd.ohiolink.edu/!etd.send_file?accession=oduhonors 1512648671501957\&disposition=inline

Rojas, R. (1994). Language and the system: the closed world of Joseph Heller's fiction. McGill University.

https://escholarship.mcgill.ca/concern/theses/gb19f809w?locale $=$ en

Said E. (2006), Wood, M. (Ed.). On Late Style: Music and Literature Against the Grain. Bloomsbury Publishing Plc.

Shakespeare, W. (1964). The Tempest. Random House.

Taş, M. R. (2017). Reading Joseph Heller's Catch-22 from the viewpoint of existential philosophy and Camus' absurdism. The Journal of International Social Research, 10(49), 56-61. 